\title{
Coastal fishes of Rio Grande do Norte, northeastern Brazil, with new records
}

\author{
José Garcia Júnior ${ }^{1 *}$, Marcelo Francisco Nóbrega ${ }^{2}$ and Jorge Eduardo Lins Oliveira ${ }^{2}$ \\ 1 Instituto Federal de Educação, Ciência e Tecnologia do Rio Grande do Norte, Campus Macau, Rua das Margaridas, 300, CEP 59500-000, \\ Macau, RN, Brazil \\ 2 Universidade Federal do Rio Grande do Norte, Departamento de Oceanografia e Limnologia, Laboratório de Biologia Pesqueira, Praia de \\ Mãe Luiza, s/nº, CEP 59014-100, Natal, RN, Brazil \\ * Corresponding author. E-mail: jose.garcia@ifrn.edu.br
}

\begin{abstract}
An updated and reviewed checklist of coastal fishes of the Rio Grande do Norte state, northeastern coast of Brazil, is presented. Between 2003 and 2013 the occurrence of fish species were recorded through collection of specimens, landing records of the artisanal fleet, literature reviews and from specimens deposited in ichthyological collections. A total of 459 species from 2 classes, 26 orders, 102 families and 264 genera is listed, with 83 species ( $18 \%$ of the total number) recorded for the first time in the study area. Additionally, Halichoeres radiatus, Lachnolaimus maximus and Canthigaster jamestyleri are reported for the first time in the Brazilian coast and nine other species have their geographic distribution extended.
\end{abstract}

Key words: ichthyofauna, marine biodiversity, Pisces, Brazilian coast

\section{INTRODUCTION}

The Rio Grande do Norte state (RN), extreme northeastern Brazil, is located in an important transition area of north-south oriented coastline that abruptly changes its direction to the east-west. In addition to this abrupt change, marked differences can also be seen along the RN shore. On the northern coast, the climate is semi-arid with annual rainfall less than $750 \mathrm{~mm}$ and predominance of northeastern winds (Nimer 1989). There are some sparse areas of beachrocks well apart from each other and three large estuarine complexes with numerous channels. The reefs are parallel to the coast and few in number, but with large areas (e.g., $20 \mathrm{~km}^{2}$ ). Some reefs are poorly known and even not mapped on the Brazilian Navy nautical charts. On the eastern coast, the climate is warm-humid with annual rainfall reaching $1,250 \mathrm{~mm}$ and with southeastern winds prevailing (Nimer 1989). The beachrocks are larger and more continuous than northern coast, the three major estuaries are small and without many ramifications, and the reefs are more numerous but smaller and relatively closer to each other than northern coast. The first and only checklist of fish species that occur along the coast of RN was produced in 1988 and comprised 190 species (Soares 1988). This situation improved after 2000 with fish surveys in specific sites of the coast (e.g., Feitoza 2001; Feitosa et al. 2002; Moura 2003; Feitoza et al. 2005; Yokota 2005; Dias 2006; Garcia Jr et al. 2010). Although such investigations have contributed to enhance the information about the local ichthyofauna, it is clear that there is a need to include all records in a single and complete list. Here, we provide an updated checklist of the fishes that occur along the coast of $\mathrm{RN}$ based on 10 years of collecting specimens, landing records of artisanal fisheries, examinations of fish collections, and reviewing previous studies of the area.

\section{MATERIALS AND METHODS \\ Study area}

Rio Grande do Norte state has about $400 \mathrm{~km}$ of coastline divided into a northern coast from Tibau, at the border with Ceará state, to Cabo Calcanhar, and an eastern coast from Cabo Calcanhar to Baía Formosa, at the border with Paraíba state (Figure 1a). The RN coast is under the influence of the surface circulation of the south Atlantic subtropical gyre, where the southern branch of the South Equatorial Current (SEC) flows westward to the Brazilian coast. The SEC bifurcates between $12^{\circ}$ and $14^{\circ} \mathrm{S}$, forming the North Brazil Current (NBC) to the north and the Brazil Current to the south (Figure $1 \mathrm{~b})$. The NBC, although weak, is constant along the Brazilian coast, where at approximately $04^{\circ} \mathrm{S}, 036^{\circ}$ $\mathrm{W}$ it joins the central branch of the SEC and increase its speed (Lumpkin and Garzoli 2005). 


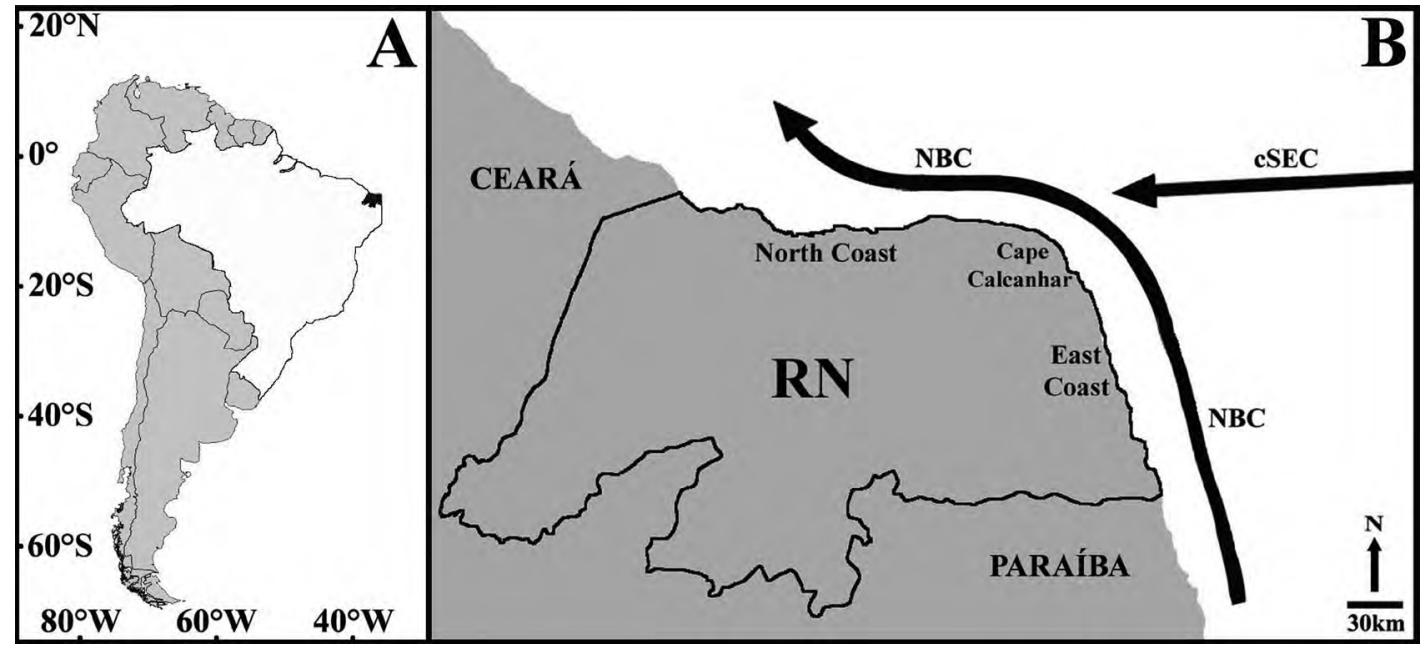

Figure 1. A: Geographical localization of the Rio Grande do Norte state (RN). B: Schematic representation of the northern and eastern coast of RN. NBC: North Brazil Current; CSEC: central branch of the South Equatorial Current.

\section{Data collection}

The records presented here were obtained between 2003 and 2013 through collection of specimens at more than 80 localities along the coast using hook and line, dip nets, trawl nets, gill nets, hand nets and plastic bags while SCUBA and free diving. During the same period, landing records of artisanal fleet were done in the main fishing ports, examining only boats fishing in localities within the limits of $\mathrm{RN}$ coast. Whenever possible, specimens with total length less than $60 \mathrm{~cm}$ were preserved and deposited in the ichthyological collection of Laboratório de Biologia Pesqueira (LABIPE) of Universidade Federal do Rio Grande do Norte (UFRN), Natal, Brazil. Additionally, literature reviews were made of fish studies carried out on the RN coast and examination of specimens deposited in the ichthyological collection at the Museu do Mar Onofre Lopes (MMOL) and the Museu de Ciências Biológicas, both from UFRN. Coastal fishes are here defined as fishes that inhabit from estuaries to the continental shelf break. On the northern coast, the continental shelf extends for $40-45 \mathrm{~km}$ from the beach line and breaks around 40-50 m depth (Amaro and Ferreira 2012), while on the eastern coast, it extends for 14-30 km and breaks in 50-60 m depth (Vital et al. 2010). Species occurrences in the RN are listed at coast level (records at northern coast and/or eastern coast) and the fish common name used by local fishermen is presented when existing. All species listed were recorded in this study, except those have only been reported in other studies carried out on the RN, which are remarked with "reported by". The species list is presented according to the phylogenetic arrangement proposed by Nelson (2006) and the taxonomy classification of Eschmeyer (2015), except for the family Ariidae (sensu Marceniuk and Menezes 2007). The genera and species are arranged within families in alphabetical order.

\section{RESULTS}

This study recorded 459 species from two classes, 26 orders, 102 families and 264 genera, with 83 species ( $18 \%$ of the total number) recorded for the first time in the study area. In addition, three new records are presented for Brazilian coast and nine extensions of species geographic distribution. In the following checklist, an asterisk $\left({ }^{*}\right)$ indicates a Brazilian endemic species and a cross $\left(^{+}\right)$indicates an endangered species in Brazil.

Class Chondrichthyes

Order Orectolobiformes

Family Ginglymostomatidae

Ginglymostoma cirratum (Bonnaterre, 1788) +

Tubarão lixa

Coast: north and east

Family Rhincodontidae

Rhincodon typus Smith, 1828

Tubarão baleia

Coast: east

Order Carcharhiniformes

Family Triakidae

Mustelus canis (Mitchill, 1815) ${ }^{+}$

Coast: unknown

Remarks: reported by Soares (1988); there are no posterior records of this species.

Family Carcharhinidae

Carcharhinus acronotus (Poey, 1860)

Cação focinhudo

Coast: north and east

Carcharhinus falciformis (Müller \& Henle, 1839)

Lombo preto

Coast: north 
Carcharhinus leucas (Müller \& Henle, 1839)

Coast: north

Reported by Yokota (2005)

Carcharhinus limbatus (Müller \& Henle, 1839)

Galha preta

Coast: north and east

Carcharhinus obscurus (Lesueur, 1818) ${ }^{+}$

Coast: unknown

Remarks: reported by Soares (1988); there are no posterior records of this species.

Carcharhinus perezi $\left(\right.$ Poey, 1876) ${ }^{+}$

Coast: north and east

Remarks: reported by Moura (2003) in northern coast and Feitoza (2001) in eastern coast

Carcharhinus plumbeus (Nardo, 1827) ${ }^{+}$

Tubarão galhudo

Coast: north and east

Carcharhinus signatus $\left(\right.$ Poey, 1868) ${ }^{+}$

Cação toninha

Coast: north and east

Galeocerdo cuvier (Péron \& Lesueur, 1822)

Tubarão tigre

Coast: north and east

Rhizoprionodon lalandii (Müller \& Henle, 1839)

Cação frango

Coast: north and east

Rhizoprionodon porosus (Poey, 1861)

Cação frango

Coast: north and east

Family Sphyrnidae

Sphyrna lewini (Griffith \& Smith, 1834) ${ }^{+}$

Tubarão martelo

Coast: north and east

Sphyrna mokarran (Rüppel, 1837) ${ }^{+}$

Tubarão martelo

Coast: north and east

Sphyrna tiburo (Linnaeus, 1758) +

Coast: unknown

Remarks: reported by Soares (1988); there are no posterior records of this species.

Order Lamniformes

Family Odontaspididae

Odontaspis ferox (Risso, 1810)

Coast: unknown

Remarks: reported by Menni et al. 1995

Family Alopiidae
Alopias superciliosus Lowe, $1841^{+}$

Tubarão raposa

Coast: north

Order Pristiophoriformes

Family Pristidae

Pristis pectinata Latham, $1794^{+}$

Coast: unknown

Remarks: reported by Soares (1988); the MMOL has

a taxidermized specimen with approximately $40 \mathrm{~cm}$ total length and a rostrum with approximately $100 \mathrm{~cm}$, both collected on the RN coast; probably old records and there are no posterior records of this species.

Order Torpediniformes

Family Narcinidae

Narcine bancrofti (Griffith \& Smith, 1834)

Treme treme

Coast: north and east

\section{Narcine sp.}

Treme treme

Coast: north

Remarks: reported by Garcia Jr et al. (2010)

Order Rajiformes

Family Rhinobatidae

Rhinobatos percellens (Walbaum, 1792) ${ }^{+}$

Cação viola

Coast: north and east

Order Myliobatiformes

Family Urotrygonidae

Urotrygon microphthalmum Delsman, 1941

Raia roliça

Coast: north and east

Family Dasyatidae

Dasyatis americana Hildebrand \& Schroeder, 1928

Raia de areia

Coast: north and east

Dasyatis centroura (Mitchill, 1815)

Raia de pedra

Coast: north and east

Dasyatis guttata (Bloch \& Schneider, 1801)

Raia pontuda

Coast: north and east

Dasyatis marianae Gomes, Rosa \& Gadig, 2000 *

Raia verde

Coast: north and east

Dasyatis say (Lesueur, 1817)

Raia

Coast: north 


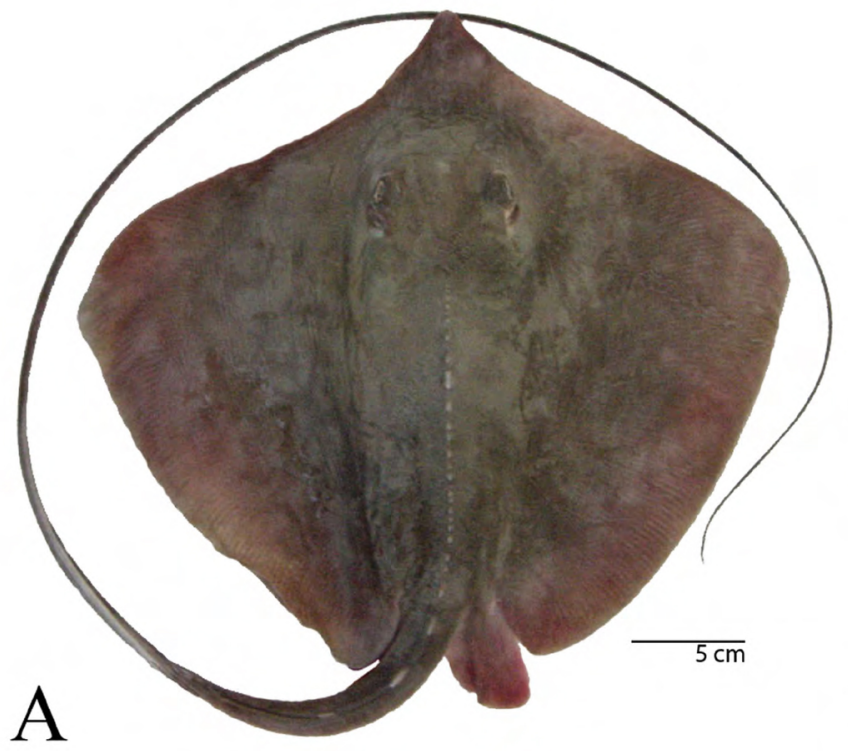

Figure 2. A: Dorsal view of Dasyatis n. sp. B: Ventral view of Dasyatis n. sp.

\section{Dasyatis n. sp.}

Raia

Coast: north

Remarks: on 7 March 2006, a specimen (LABIPE 32) of the genus Dasyatis was collected in front of Guamaré, northern coast, on sandy substrate in $12 \mathrm{~m}$ depth with trawl net. The female specimen measuring $31 \mathrm{~cm}$ disc width and $800 \mathrm{~g}$ total weight, was not identified as any Atlantic species described for the genus, being similar to Dasyatis guttata, but with more elongated snout, with pelvic fins projected beyond the posterior margin of the disc and a longer tail (Figure $2 \mathrm{a}$ and $2 \mathrm{~b}$ ). This species is under description process.

\section{Family Gymnuridae}

\section{Gymnura micrura (Bloch \& Schneider, 1801)}

Raia manteiga

Coast: north and east

Family Myliobatidae

Aetobatus narinari (Euphrasen, 1790)

Raia pintada

Coast: north and east

Manta birostris (Donndorff, 1798)

Raia manta

Coast: north and east

Mobula hypostoma (Bancroft, 1831)

Coast: north

Remarks: reported by Yokota (2005)

Mobula tarapacana (Philippi, 1892) +

Raia manta

Coast: north and east

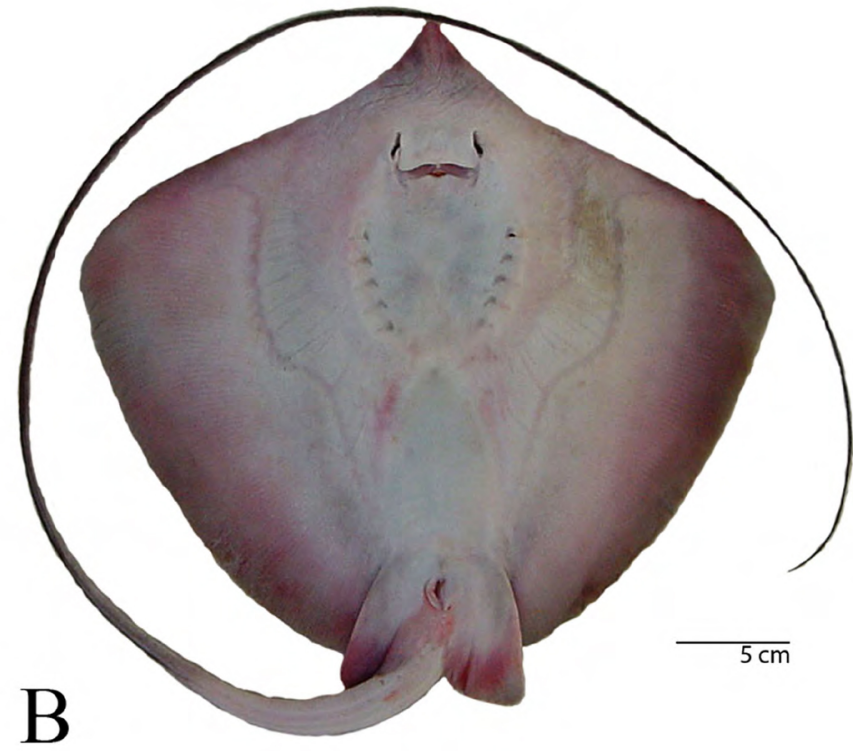

Rhinoptera bonasus (Mitchill, 1815)

Cara de vaca

Coast: north and east

Class Actinopterygii

Order Elopiformes

Family Elopidae

Elops saurus Linnaeus, 1766

Ubarana

Coast: north and east

Family Megalopidae

Megalops atlanticus Valenciennes, $1847^{+}$

Camurupim

Coast: north and east

Order Albuliformes

Family Albulidae

Albula nemoptera (Fowler, 1911)

Ubarana fucinho de rato

Coast: north and east

Albula vulpes (Linnaeus, 1758)

Ubarana focinho de rato

Coast: north and east

Order Anguilliformes

Family Chlopsidae

Chilorhinus suensonii Lütken, 1852

Coast: north

Remarks: reported by Moura (2003) 
Family Muraenidae

Channomuraena vittata (Richardson, 1845)

Moréia

Coast: north

Remarks: reported by Garcia Jr et al. (2010)

Enchelycore carychroa Böhlke \& Böhlke, 1976 Coast: north

Remarks: reported by Moura (2003)

Enchelycore nigricans (Bonaterre, 1788)

Moréia

Coast: north and east

Gymnothorax funebris Ranzani, 1840

Moréia verde

Coast: north and east

Gymnothorax miliaris (Kaup, 1856)

Moréia amarela

Coast: north and east

Gymnothorax moringa (Cuvier, 1829)

Moréia pintada

Coast: north and east

Gymnothorax ocellatus Agassiz, 1831

Moréia pintada

Coast: north and east

Gymnothorax vicinus (Castelnau, 1855)

Moréia marrom

Coast: north and east

Muraena pavonina Richardson, 1845

Moréia amarela

Coast: north and east

Uropterygius macularius (Lesueur, 1825)

Coast: north

Remarks: reported by Ramos (1994) and Moura (2003).

Family Ophichthidae

Ahlia egmontis (Jordan, 1884)

Muriongo

Coast: north and east

Myrichthys breviceps (Richardson, 1848)

Mututuca

Coast: east

Myrichthys ocellatus (Lesueur, 1825)

Mututuca

Coast: north and east

Myrophis punctatus Lütken, 1851

Mututuca

Coast: north and east
Ophichthus cylindroideus (Ranzani, 1839)

Muriongo

Coast: east

Ophichthus ophis (Linnaeus, 1758)

Muriongo

Coast: north and east

Family Congridae

Heteroconger camelopardalis (Lubbock, 1980)

Muriongo

Coast: north and east

Order Clupeiformes

Family Pristigasteridae

Chirocentrodon bleekerianus (Poey, 1867)

Sardinha dentuça

Coast: north and east

Pellona harroweri (Fowler, 1919)

Sardinha manteiga

Coast: north and east

Family Engraulidae

Anchoa filifera (Fowler, 1915)

Arenque

Coast: north and east

Anchoa januaria Hildebrand, 1943

Arenque

Coast: north

Anchoa lyolepis (Evermann \& Marsh, 1902)

Arenque

Coast: east

Anchoa spinifer (Valenciennes, 1848)

Arenque branco

Coast: north and east

Anchoa tricolor (Agassiz, 1829)

Arenque

Coast: north

Anchovia clupeoides (Swainson, 1839)

Arenque

Coast: north and east

Anchoviella lepidentostole (Fowler, 1911)

Arenque

Coast: north and east

Cetengraulis edentulus (Cuvier, 1829)

Arenque roliço

Coast: north and east

Lycengraulis batesii (Günther, 1868)

Arenque

Coast: north

Remarks: on 18 April 2013, a specimen (LABIPE 


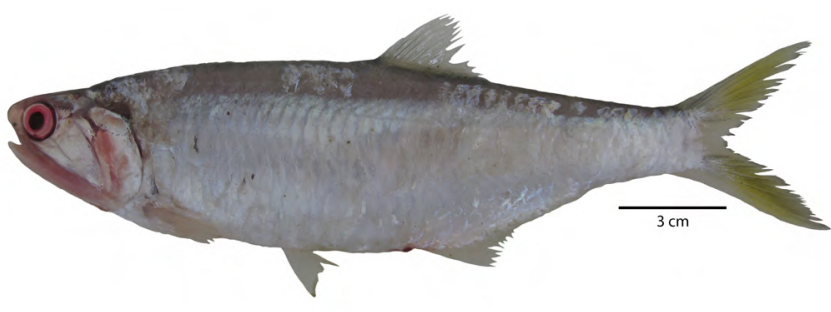

Figure 3. Lycengraulis batesii (photo J. Garcia Jr).

1027) was collected in front of São Cristóvão beach, northern coast, on gravel substrate in $14 \mathrm{~m}$ depth with gill net. The specimen measured $24 \mathrm{~cm}$ total length and $135 \mathrm{~g}$ total weight (Figure 3). The species is found only in the northern region of Brazil (Menezes et al. 2003; Montag et al. 2009) and the present record represents the southernmost occurrence and extension of its geographical distribution. New record for the northeastern Brazil.

\section{Lycengraulis grossidens (Agassiz, 1829)}

Arenque

Coast: north and east

Family Clupeidae

Harengula clupeola (Cuvier, 1829)

Sardinha cascuda

Coast: north and east

Harengula jaguana (Poey, 1865)

Sardinha cascuda

Coast: north and east

Lile piquitinga (Schreiner \& Miranda Ribeiro, 1903)

Pititinga

Coast: north and east

Odontognathus mucronatus (Lacepède, 180o)

Arenque branco

Coast: north and east

Opisthonema oglinum (Lesueur, 1818)

Sardinha de laje

Coast: north and east
Rhinosardinia bahiensis (Steindachner, 1879)

Sardinha cascuda

Coast: north and east

Order Siluriformes

Family Ariidae

Aspistor luniscutis (Valenciennes, 1840)

Bagre amarelo

Coast: north and east

Aspistor parkeri (Traill, 1832)

Bagre

Coast: east

Bagre bagre (Linnaeus, 1766)

Bagre fita

Coast: north and east

Bagre marinus (Mitchill, 1815)

Bagre bandeira

Coast: north and east

Cathorops agassizii (Eigenmann \& Eigenmann, 1988)

Bagre branco

Coast: north and east

Cathorops spixii (Agassiz, 1829)

Bagre amarelo

Coast: north and east

Genidens barbus (Lacepède, 1803) +

Bagre ariaçú

Coast: north and east

Remarks: on 3 November 2006, 24 specimens (LABIPE 49-72) were collected in Pirangi beach, eastern coast, on sandy substrate in about $1 \mathrm{~m}$ depth with hook and line. The specimens measured between 13 and $29 \mathrm{~cm}$ total length and 14 and $159 \mathrm{~g}$ total weight (Figure $4 \mathrm{a}$ and 4b). Additionally, other specimens were also recorded in several localities at northern and eastern coast of $\mathrm{RN}$. According to Marceniuk (2005), the species is found in Brazil from southern Bahia to Rio Grande do Sul states. Therefore, the present records are the northernmost occurrence and extends its geographical distribution.
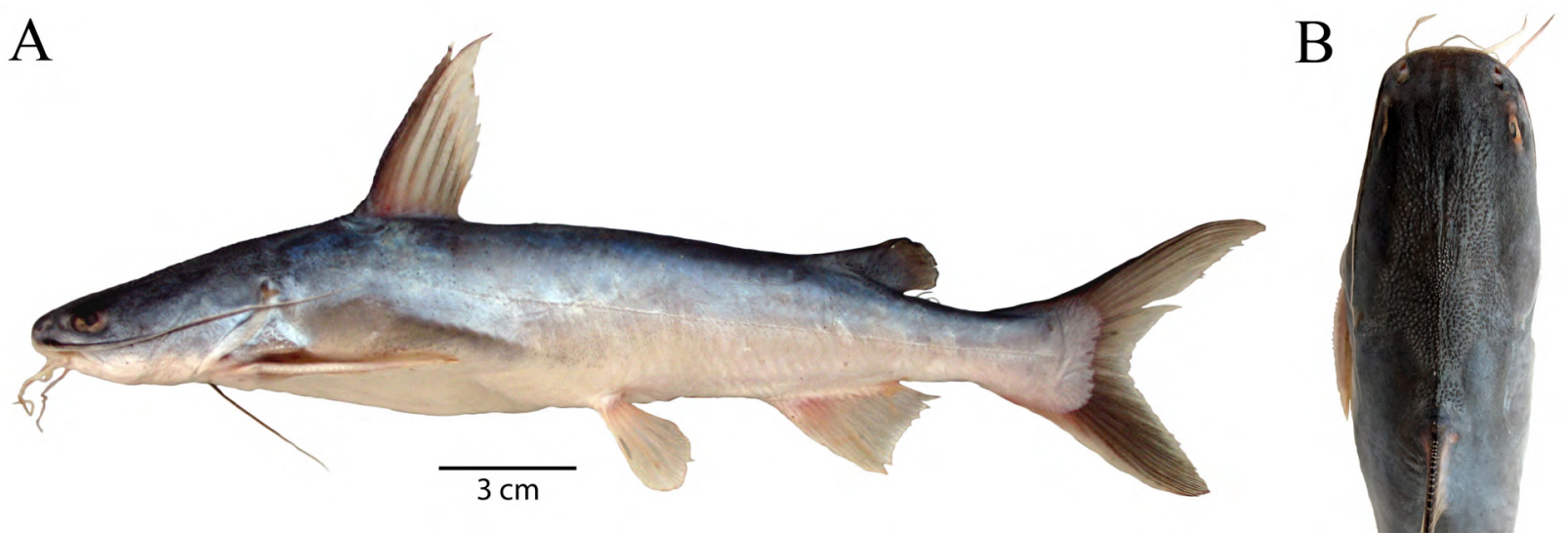

Figure 4. A: Lateral view of Genidens barbus. B: Dorsal view of Genidens barbus (photos J. Garcia Jr). 
Notarius grandicassis (Valenciennes, 1840)

Bagre ariaçú

Coast: north and east

Sciades herzbergii (Bloch, 1794)

Bagre mandim

Coast: north and east

Sciades proops (Valenciennes, 1840)

Bagre mandim

Coast: north and east

Order Aulopiformes

Family Synodontidae

Synodus foetens (Linnaeus, 1766)

Peixe lagarto

Coast: north and east

Synodus intermedius (Spix \& Agassiz, 1829)

Peixe lagarto

Coast: north and east

Synodus poeyi Jordan, 1887

Peixe lagarto

Coast: north and east

Trachinocephalus myops (Forster, 1801)

Peixe lagarto

Coast: north and east

Order Polymixiiformes

Family Polymixiidae

Polymixia lowei Günther, 1859

Barbudo olhão

Coast: east

Order Ophidiiformes

Family Ophidiidae

Lepophidium cf. brevibarbe (Cuvier, 1829) Coast: north

Remarks: reported by Garcia Jr et al. (2010)

Ophidion cf. holbrookii (Putnam, 1874) +

Coast: north

Remarks: reported by Garcia Jr et al. (2010)

Order Batrachoidiformes

Family Batrachoididae

Amphichthys cryptocentrus (Valenciennes, 1837)

Pacamão

Coast: north and east

Porichthys plectrodon Goode \& Bean, 1882

Mangangá

Coast: north and east

Thalassophryne nattereri Steindachner, 1876

Anequim

Coast: north and east
Thalassophryne punctata Steindachner, 1876 *

Anequim

Coast: north

Order Lophiiformes

Family Antennariidae

Antennarius multiocellatus (Valenciennes, 1837)

Antenarius

Coast: north and east

Antennarius striatus (Shaw \& Nodder, 1794)

Antenarius

Coast: north and east

Histrio histrio (Linnaeus, 1758)

Peixe sargaço

Coast: east

Family Ogcocephalidae

Ogcocephalus vespertilio (Linnaeus, 1758)

Peixe morcego

Coast: north and east

Order Mugiliformes

Family Mugilidae

Mugil brevirostris (Ribeiro, 1915)

Tamatarãna

Coast: north and east

Mugil curema Valenciennes, 1836

Tainha

Coast: north and east

Mugil curvidens Valenciennes, 1836

Tainha

Coast: east

Mugil liza Valenciennes, 1836

Cacetão

Coast: north and east

Mugil rubrioculus Harrison, Nirchio, Oliveira, Ron \& Gavíria, 2007

Tainha roliça

Coast: north and east

Order Atheriniformes

Family Atherinopsidae

Atherinella blackburni (Schultz, 1949)

Ginga

Coast: north and east

Remarks: on 1 January 2007, a specimen (LABIPE 146) was collected in Grossos, northern coast, in an estuary channel in $0.5 \mathrm{~m}$ depth with hand net, together with several specimens of Atherinella brasiliensis. The specimen measured $9 \mathrm{~cm}$ in total length and $7 \mathrm{~g}$ total weight (Figure 5). Additionally, other specimens were also recorded in several localities at northern and eastern coast of RN. According to Mattox et al. (2008), the species 


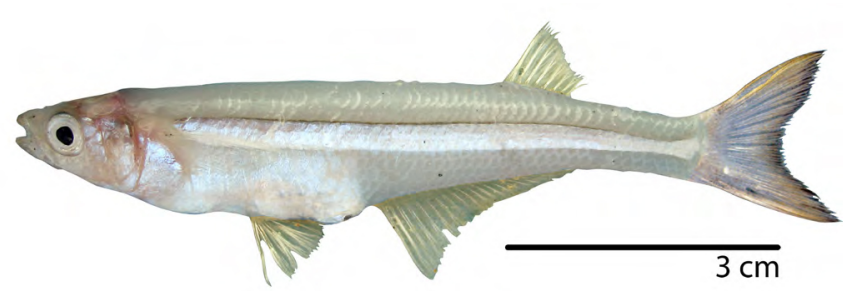

Figure 5. Atherinella blackburni (photo J. Garcia Jr).

is discontinuously found in western Atlantic Ocean in localities of Costa Rica, Panama, Venezuela and in Brazil at Alagoas, Bahia, Rio de Janeiro and São Paulo states. Thus, the occurrence on the $\mathrm{RN}$ coast extends the geographic distribution of this species in Brazil and may indicate that the discontinuity of records is possibly caused by misidentifications of $A$. brasiliensis, a very similar species.

Atherinella brasiliensis (Quoy \& Gaimard, 1824) Ginga

Coast: north and east

Order Beloniformes

Family Exocoetidae

Cheilopogon cyanopterus (Valenciennes, 1847)

Voador holandês

Coast: north and east

Cheilopogon melanurus (Valenciennes, 1847)

Voador

Coast: north and east

Cheilopogon pinnatibarbatus (Bennet, 1831)

Voador

Coast: east

Exocoetus volitans Linnaeus, 1758

Voador

Coast: north and east

Hirundichthys affinis (Günther, 1866)

Voador

Coast: north and east

Family Hemiramphidae

Euleptorhamphus velox Poey, 1868

Agulha padá

Coast: north and east

Hemiramphus balao Lesueur, 1821

Agulha vermelha

Coast: north and east

Hemiramphus brasiliensis (Linnaeus, 1758)

Agulha preta

Coast: north and east

Hyporhamphus roberti (Valenciennes, 1846)

Agulha branca

Coast: north and east
Hyporhamphus unifasciatus (Ranzani, 1842)

Agulha verde

Coast: north and east

Family Belonidae

Ablennes hians (Valenciennes, 1846)

Agulhão listrado

Coast: north and east

Strongylura marina (Walbaum, 1792)

Agulhão catarro

Coast: north and east

Strongylura timucu (Walbaum, 1792)

Agulhão azul

Coast: north and east

Tylosurus acus (Lacepède, 1803)

Agulhão zambaio

Coast: north and east

Tylosurus crocodilus (Péron \& Lesueur, 1821)

Agulhão surrupeio

Coast: north and east

Order Cyprinodontiformes

Family Anablepidae

Anableps anableps (Linnaeus, 1758)

Tralhoto

Coast: north and east

Anableps microlepis Müller \& Troschel, 1844

Tralhoto

Coast: north

Remarks: on 3 January 2007, two specimens (LABIPE 119 and 120) were collected in São Cristóvão beach, northern coast, on sandy substrate in $0.2 \mathrm{~m}$ depth with hand net. The specimens measured 13 and $16 \mathrm{~cm}$ total length and 13 and $16 \mathrm{~g}$ total weight (Figure 6). Additionally, other specimens were also recorded in some localities at northern coast of RN. The species is recorded in Brazil only in the northern region, in Amapá, Pará and Maranhão states (Martins-Juras et al. 1987; Carvalho-Filho 1999; Camargo and Isaac 2001). Thus, present records are the southernmost occurrence and extends its geographical distribution. New record for the northeastern Brazil.

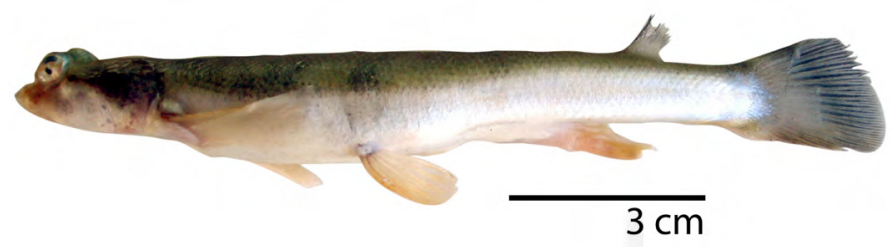

Figure 6. Anableps microlepis (photo J. Garcia Jr). 
Family Poeciliidae

Poecilia vivipara Bloch \& Schneider, 1801

Barrigudinho

Coast: north and east

Order Beryciformes

Family Holocentridae

Holocentrus adscensionis (Osbeck, 1765)

Mariquita

Coast: north and east

Myripristis jacobus Cuvier, 1829

Mariquita bolão

Coast: north and east

Plectrypops retrospinis (Guichenot, 1853)

Coast: east

Remarks: reported by Feitoza (2001)

Order Gasterosteiformes

Family Syngnathidae

Hippocampus erectus Perry, $1810^{+}$

Cavalo marinho

Coast: north and east

Hippocampus reidi Ginsburg, $1933^{+}$

Cavalo marinho

Coast: north and east

Micrognathus crinitus (Jenyns, 1842)

Peixe cachimbo

Coast: east

Micrognathus erugatus Herald \& Dawson, $1974^{*+}$

Peixe cachimbo

Coast: north

Family Aulostomidae

Aulostomus strigosus Wheeler, 1955

Peixe trombeta

Coast: north and east

Family Fistularidae

Fistularia tabacaria Linnaeus, 1758

Peixe trombeta

Coast: north and east

Order Scorpaeniformes

Family Dactylopteridae

Dactylopterus volitans (Linnaeus, 1758)

Coió

Coast: north and east

Family Scorpaenidae

Scorpaena brasiliensis Cuvier, 1829

Mangangá vermelho

Coast: north and east
Scorpaena dispar Longley \& Hildebrand, 1940

Mangangá

Coast: north

Scorpaena inermis Cuvier, 1829

Mangangá

Coast: north

Scorpaena isthmensis Meek \& Hildebrand, 1928

Mangangá

Coast: north and east

Scorpaena melasma Eschmeyer, 1965

Mangangá

Coast: north

Remarks: on 4 September 2004, a specimen (LABIPE

17) was collected in front of Upanema beach, northern coast, on gravel substrate in $15 \mathrm{~m}$ depth with trawl net. The specimen measured $10 \mathrm{~cm}$ total length and 37 $\mathrm{g}$ total weight (Figure 7). The species is found in Brazil only in the northern region (Menezes et al. 2003) and the present record is the southernmost occurrence and extends its geographical distribution. New record for the northeastern Brazil.

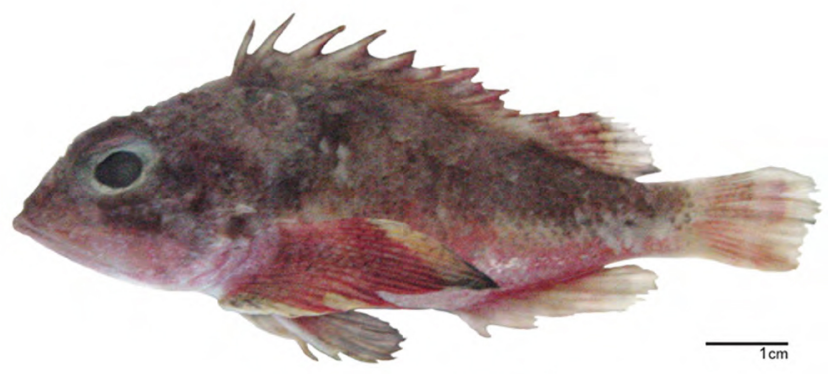

Figure 7. Scorpaena melasma (photo J. Garcia Jr).

\section{Scorpaena plumieri Bloch, 1789}

Beatriz

Coast: north and east

\section{Scorpaena n. sp.}

Mangangá

Coast: north

Remarks: on 24 June 2004, a specimen (LABIPE 12) of the genus Scorpaena was collected in front of Porto do Mangue, northern coast, on gravel substrate in $9 \mathrm{~m}$ depth with trawl net. The specimen measuring $18 \mathrm{~cm}$ total length and $230 \mathrm{~g}$ total weight was not identified as any Atlantic species described for the genus, due the presence of a conspicuous backturned V-shaped mark on the nape (Figure $8 \mathrm{a}$ and $8 \mathrm{~b}$ ). This species is under description process.

Scorpaenodes caribbaeus Meek \& Hildebrand, 1928 Coast: north and east

Scorpaenodes tredecimspinosus Metzelaar, 1919 Coast: north and east 

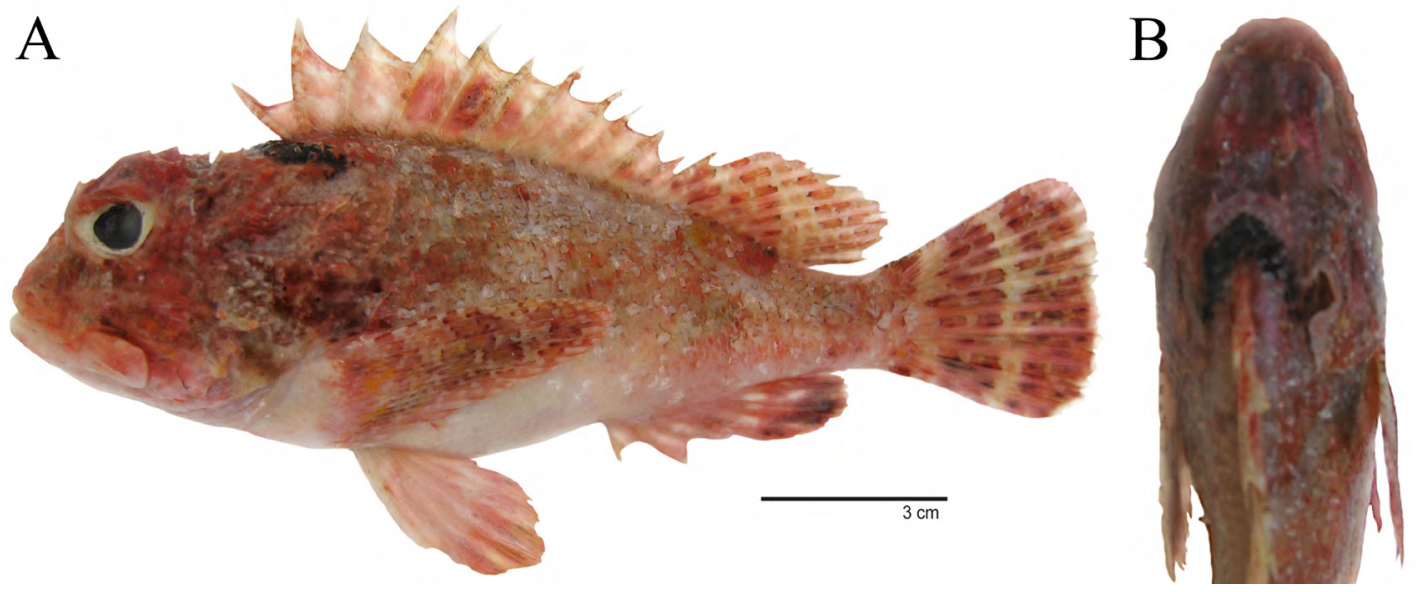

Figure 8. A: Lateral view of Scorpaena n. sp. B: Dorsal view of Scorpaena n. sp. (photos J. Garcia Jr).

Family Triglidae

Prionotus punctatus (Bloch, 1793)

Cabrinha

Coast: north and east

Order Perciformes

Family Centropomidae

Centropomus ensiferus Poey, 1860

Camurim suvela

Coast: north and east

Centropomus mexicanus Bocourt, 1868

Camurim

Coast: east

Centropomus parallelus Poey, 1860

Camurim corcunda

Coast: north and east

Centropomus pectinatus Poey, 1860

Camurim de espinho

Coast: north and east

Centropomus undecimalis (Bloch, 1796)

Camurim açú

Coast: north and east

Family Serranidae

\footnotetext{
Alphestes afer (Bloch, 1793)

Guaçapé

Coast: north and east
}

\section{Cephalopholis fulva (Linnaeus, 1758)}

Piraúna

Coast: north and east

Dermatolepis inermis (Valenciennes, 1833)

Gostosa

Coast: north and east

Diplectrum formosum (Linnaeus, 1766)

Jacundá

Coast: north and east
Diplectrum radiale (Quoy \& Gaimard, 1824)

Jacundá

Coast: north

Epinephelus adscensionis (Osbeck, 1765)

Peixe gato

Coast: north and east

Epinephelus itajara (Lichtenstein, 1822) ${ }^{+}$

Mero

Coast: north and east

Epinephelus morio (Valenciennes, 1828)

Garoupa verdadeira

Coast: north and east

Epinephelus nigritus (Holbrook, 1855)

Garoupa

Coast: east

Epinephelus niveatus (Valenciennes, 1828)

Garoupa pintada

Coast: east

Gonioplectrus hispanus (Cuvier, 1828)

Coast: north

Remarks: on 17 June 2009, a specimen was collected in front of Caiçara do Norte beach, northern coast, on rocky substrate in about $40 \mathrm{~m}$ depth by a boat fishing with gill nets. The specimen measured $29 \mathrm{~cm}$ total length and $380 \mathrm{~g}$ total weight (Figure 9). In Brazil, the species is recorded only in Trindade Island, $1160 \mathrm{~km}$ distant from the coast of Espírito Santo state (Gasparini and Floeter 2001) and in Pernambuco state (Oliveira and Barbosa 2010). The present record is the northernmost occurrence and extends its geographical distribution.

Mycteroperca bonaci (Poey, 1860) ${ }^{+}$

Serigado

Coast: north and east

Mycteroperca interstitialis (Poey, 1860) ${ }^{+}$

Coast: east

Remarks: reported by Feitoza (2001) 


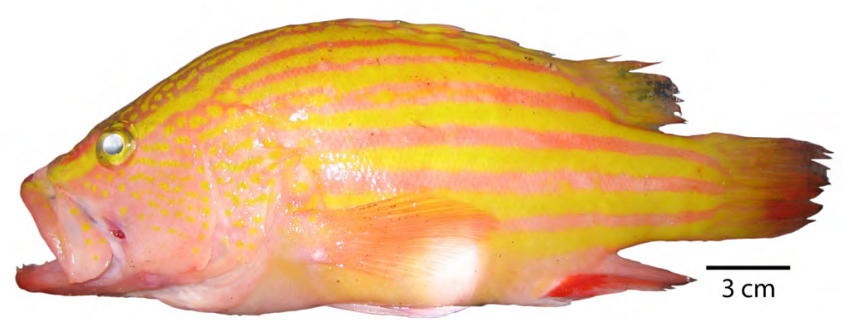

Figure 9. Gonioplectrus hispanus (photo M.F. Nóbrega).

\section{Mycteroperca tigris (Valenciennes, 1833)}

Coast: north

Remarks: reported by Moura (2003)

Mycteroperca venenosa (Linnaeus, 1758)

Serigado

Coast: east

Paralabrax dewegeri (Metzelaar, 1919)

Badejo mirim

Coast: north

Remarks: reported by Garcia Jr et al. (2010)

Paranthias furcifer (Valenciennes, 1828)

Guaiúba açú

Coast: north and east

Rypticus bistrispinus (Mitchill, 1818)

Sabão

Coast: north and east

Rypticus randalli Courtenay, 1967

Sabão

Coast: east

Rypticus saponaceus (Bloch \& Schneider, 1801)

Sabão

Coast: north and east

Rypticus subbifrenatus Gill, 1861

Sabão

Coast: north and east

Serranus annularis (Günther, 1880)

Badejo mirim

Coast: north and east

Serranus baldwini (Evermann \& Marsh, 1900)

Coast: north and east

Serranus flaviventris (Cuvier, 1829)

Badejo mirim

Coast: north and east

Family Grammatidae

Gramma brasiliensis Sazima, Gasparini \& Moura, 1998 * Grama

Coast: north and east
Family Opistognathidae

Opistognathus aff. aurifrons (Jordan \& Thompson, 1905)

Coast: east

Remarks: reported by Feitoza et al. (2005)

\section{Opistognathus sp.}

Coast: north and east

Remarks: reported by Moura (2003) in northern coast and Feitoza (2001) in eastern coast

Family Priacanthidae

Cookeolus japonicus (Cuvier, 1829)

Olho de boi

Coast: north and east

Heteropriacanthus cruentatus (Lacepède, 1801)

Olho de vidro

Coast: north and east

Priacanthus arenatus Cuvier, 1829

Olho de cão

Coast: north and east

Pristygenys alta (Gill, 1862)

Olho de vidro

Coast: north and east

Family Apogonidae

Apogon americanus Castelnau, 1855*

Apogon

Coast: north and east

Apogon planifrons Longley \& Hildebrand, 1940

Apogon

Coast: north and east

Apogon pseudomaculatus Longley, 1932

Apogon

Coast: north and east

Apogon quadrisquamatus Longley, 1934

Apogon

Coast: north and east

Astrapogon puncticulatus (Poey, 1867)

Apogon

Coast: north and east

Phaeoptyx pigmentaria (Poey, 1860)

Apogon

Coast: north and east

Family Malacanthidae

Malacanthus plumieri (Bloch, 1786)

Pirá

Coast: north and east 

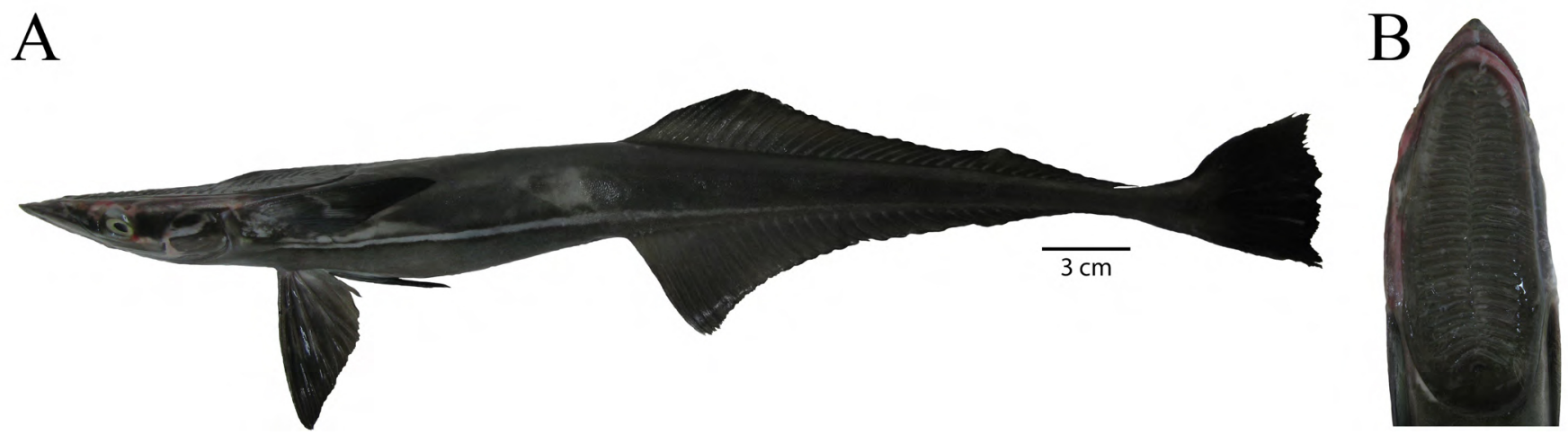

Figure 10. A: Lateral view of Echeneis neucratoides, B: Dorsal view of Echeneis neucratoides (photos J. Garcia Jr).

Family Pomatomidae

Pomatomus saltatrix (Linnaeus, 1766)

Enchova

Coast: east

Family Rachycentridae

Rachycentron canadum (Linnaeus, 1766)

Bijupirá

Coast: north and east

Family Echeneidae

Echeneis naucrates Linnaeus, 1758

Peixe piolho

Coast: north and east

Echeneis neucratoides Zuiew, 1789

Peixe piolho

Coast: east

Remarks: on 18 April 2013, a specimen (LABIPE 1028) was collected in front of São Cristóvão beach, northern coast, on gravel substrate in $14 \mathrm{~m}$ depth with gill net. The species measured $45 \mathrm{~cm}$ total length and $370 \mathrm{~g}$ total weight (Figure 10). The species is found in Brazil only in the northern region (Carvalho-Filho 1999) and the present record is the southernmost occurrence and extends its geographical distribution. New record for the northeastern Brazil.

Remora osteochir (Cuvier, 1829)

Piolho de agulhão

Coast: east

Family Coryphaenidae

Coryphaena equiselis Linnaeus, 1758

Azedinho

Coast: north and east

Coryphaena hippurus Linnaeus, 1758

Dourado

Coast: north and east
Family Carangidae

Alectis ciliaris (Bloch, 1787)

Galo do alto

Coast: north and east

Carangoides bartholomaei (Cuvier, 1833)

Guarajuba amarela

Coast: north and east

Carangoides ruber (Bloch, 1793)

Guarajuba azul

Coast: north and east

Caranx crysos (Mitchill, 1815)

Guaraxumba

Coast: north and east

Caranx hippos (Linnaeus, 1766)

Xaréu amarelo

Coast: north and east

Caranx latus Agassiz, 1831

Garacimbora

Coast: north and east

Caranx lugubris Poey, 1860

Pargo ferreiro

Coast: north and east

Chloroscombrus chrysurus (Linnaeus, 1766)

Palombeta

Coast: north and east

Decapterus macarellus (Cuvier, 1833)

Carapau verde

Coast: north and east

Decapterus punctatus (Cuvier, 1829)

Carapau

Coast: north and east

Decapterus tabl Berry, 1968

Carapau cavalinha

Coast: north and east 
Elagatis bipinnulata (Quoy \& Gaimard, 1825)

Peixe rei

Coast: north and east

Hemicaranx amblyrhinchus (Cuvier, 1833)

Vento leste

Coast: north and east

Naucrates ductor (Linnaeus, 1758)

Peixe piloto

Coast: north and east

Oligoplites palometa (Cuvier, 1832)

Tibiro

Coast: north and east

Oligoplites saurus (Bloch, 1793)

Tibiro

Coast: north and east

Pseudocaranx dentex (Bloch \& Schneider, 1801)

Garapoá

Coast: north and east

Selar crumenophthalmus (Bloch, 1793)

Carapau olhudo

Coast: north and east

Selene brownii (Cuvier, 1816)

Peixe galo

Coast: north and east

Selene setapinnis (Mitchill, 1815)

Peixe galo

Coast: north and east

Selene vomer (Linnaeus, 1758)

Peixe galo

Coast: north and east

Seriola dumerili (Risso, 1810)

Arabaiana

Coast: north and east

Seriola rivoliana Valenciennes, 1833

Arabaiana

Coast: north and east

Trachinotus carolinus (Linnaeus, 1766)

Pampo

Coast: north and east

Trachinotus falcatus (Linnaeus, 1758)

Carabebéu

Coast: north and east

Trachinotus goodei Jordan \& Evermann, 1896

Aracanguira

Coast: north and east

Uraspis secunda (Poey, 1860)

Cara de gato

Coast: east
Family Lutjanidae

Etelis oculatus (Valenciennes, in Cuvier \& Valenciennes, 1828)

Mariquitão

Coast: north and east

Lutjanus alexandrei Moura \& Lindeman, 2007 *

Vermelho

Coast: north and east

Lutjanus analis (Cuvier, 1828)

Cioba

Coast: north and east

Lutjanus buccanella (Cuvier, 1828)

Boca negra

Coast: north and east

Lutjanus cyanopterus (Cuvier, 1828) ${ }^{+}$

Caranha

Coast: north and east

Lutjanus jocu (Bloch \& Schneider, 1801)

Dentão

Coast: north and east

Lutjanus purpureus (Cuvier, 1828) ${ }^{+}$

Pargo cachucho

Coast: north and east

Lutjanus synagris (Linnaeus, 1758)

Ariocó

Coast: north and east

Lutjanus vivanus (Cuvier, 1828)

Pargo olho de vidro

Coast: north and east

Ocyurus chrysurus (Bloch, 1791)

Guaiúba

Coast: north and east

Rhomboplites aurorubens (Cuvier, 1828)

Pirapiranga

Coast: north and east

Family Lobotidae

Lobotes surinamensis (Bloch, 1790)

Dorminhoco

Coast: north and east

Family Gerreidae

Diapterus auratus Ranzani, 1840

Carapeba branca

Coast: north and east

Diapterus rhombeus (Valenciennes, 1830)

Carapeba branca

Coast: north and east 
Eucinostomus argenteus Baird \& Girard, 1855

Carapicú

Coast: north and east

Eucinostomus gula (Quoy \& Gaimard, 1824)

Carapicú

Coast: north and east

Eucinostomus harengulus Baird \& Girard, 1855

Carapicú

Coast: north

\section{Eucinostomus havana (Nichols, 1912) \\ Carapicú \\ Coast: north}

Eucinostomus jonesii (Günther, 1879)

Carapicú

Coast: north

Remarks: on 20 January 2007, a specimen (LABIPE 214) was collected in Diogo Lopes, northern coast, in an estuary channel in $0.5 \mathrm{~m}$ depth with hand net. The specimen measured $10 \mathrm{~cm}$ total length and $24 \mathrm{~g}$ total weight (Figure 11). In the western Atlantic Ocean, the species is described to occur from Florida and Bermudas to Brazil (Menezes et al. 2003), but without specifying sites at Brazilian coast in which it has been registered. This record confirms its occurrence in northeastern Brazil.

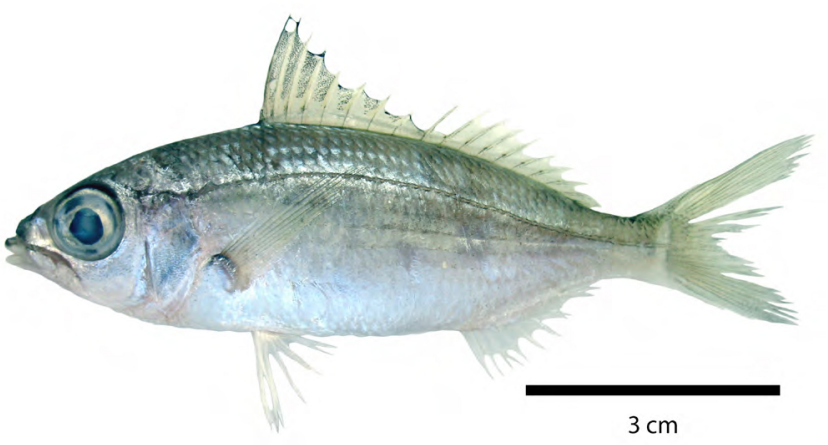

Figure 11. Eucinostomus jonesii (photo J. Garcia Jr).

\section{Eucinostomus lefroyi (Goode, 1874)}

Carapicú pintado

Coast: north and east

Eucinostomus melanopterus (Bleeker, 1863)

Carapicú

Coast: north and east

Eugerres brasilianus (Valenciennes, 1830)

Carapeba listrada

Coast: north and east

Gerres cinereus (Walbaum, 1792)

Carapicú açú

Coast: north and east
Family Haemulidae

Anisotremus moricandi Ranzani, 1842

Zumbi

Coast: north and east

Anisotremus surinamensis (Bloch, 1791)

Pirambú

Coast: north and east

Anisotremus virginicus (Linnaeus, 1758)

Mercador amarelo

Coast: north and east

Conodon nobilis (Linnaeus, 1758)

Coró amarelo

Coast: north and east

Genyatremus luteus (Bloch, 1795)

Sanhoá

Coast: north and east

Haemulon aurolineatum (Cuvier, 1830)

Xira branca

Coast: north and east

Haemulon melanurum (Linnaeus, 1758)

Xirão

Coast: north and east

Haemulon parra (Desmarest, 1823)

Cambuba

Coast: north and east

Haemulon plumierii (Lacepède, 1802)

Biquara

Coast: north and east

Haemulon sciurus (Shaw, 1803)

Coast: unknown

Remarks: reported by Soares (1988); there are no posterior records of this species.

Haemulon squamipinna Rocha \& Rosa, 1999 *

Xira listrada

Coast: north and east

Haemulon steindachneri (Jordan \& Gilbert, 1882)

Sapuruna

Coast: north and east

Haemulon striatum (Linnaeus, 1758)

Coast: unknown

Remarks: reported by Soares (1988); there are no posterior records of this species.

Orthopristis ruber (Cuvier, 1830)

Canguito

Coast: north and east

Pomadasys corvinaeformis (Steindachner, 1868)

Coró branco

Coast: north and east 
Pomadasys crocro (Cuvier, 1830)

Espinho duro

Coast: east

Family Sparidae

Archosargus probatocephalus (Walbaum, 1792)

Sargo de dente

Coast: north and east

Archosargus rhomboidalis (Linnaeus, 1758)

Salema

Coast: north and east

Calamus calamus (Valenciennes, 1830)

Pena

Coast: north and east

Calamus penna (Valenciennes, 1830)

Pena

Coast: north and east

Calamus pennatula Guichenot, 1868

Pena

Coast: north and east

Family Polynemidae

Polydactylus oligodon (Günther, 1860)

Barbudo preto

Coast: north and east

Polydactylus virginicus (Linnaeus, 1758)

Barbudo amarelo

Coast: north and east

Family Sciaenidae

Bairdiella ronchus (Cuvier, 1830)

Pescada espinho duro

Coast: north and east

Cynoscion acoupa (Lacepède, 1801)

Pescada amarela

Coast: north and east

Cynoscion leiarchus (Cuvier, 1830)

Pescada branca

Coast: north and east

Cynoscion microlepidotus (Cuvier, 1830)

Pescadinha

Coast: north and east

Cynoscion virescens (Cuvier, 1830)

Pescada traíra

Coast: east

Equetus lanceolatus (Linnaeus, 1758)

Coast: north

Isopisthus parvipinnis (Cuvier, 1830)

Pescada de dente

Coast: north and east
Larimus breviceps Cuvier, 1830

Boca mole

Coast: north and east

Macrodon ancylodon (Bloch \& Schneider, 1801)

Pescada foguete

Coast: north and east

Menticirrhus americanus (Linnaeus, 1758)

Judeu

Coast: north and east

Menticirrhus littoralis (Holbrook, 1847)

Judeu

Coast: north and east

Micropogonias furnieri (Desmarest, 1823)

Cururuca

Coast: north and east

Nebris microps Cuvier, 1830

Pesca banana

Coast: north and east

Odontoscion dentex (Cuvier, 1830)

Pescada de pedra

Coast: north and east

Ophioscion punctatissimus Meek \& Hildebrand, 1925

Pescada cabeça dura

Coast: north and east

Paralonchurus brasiliensis (Steindachner, 1875)

Maria mole

Coast: north and east

Pareques acuminatus (Bloch \& Schneider, 1801)

Canivete

Coast: north and east

Stellifer brasiliensis (Schultz, 1945)*

Cangoá

Coast: east

Remarks: on 8 August 2006, a specimen (LABIPE 38) was collected in Tabatinga beach, eastern coast, on sandy substrate in about $0.5 \mathrm{~m}$ depth with hand net. The specimen measured $9 \mathrm{~cm}$ total length and $7 \mathrm{~g}$ total weight (Figure 12). The species is found in Brazil from Pernambuco to São Paulo states (Vasconselos-Filho and Oliveira 1999; Menezes et al. 2003) and the present

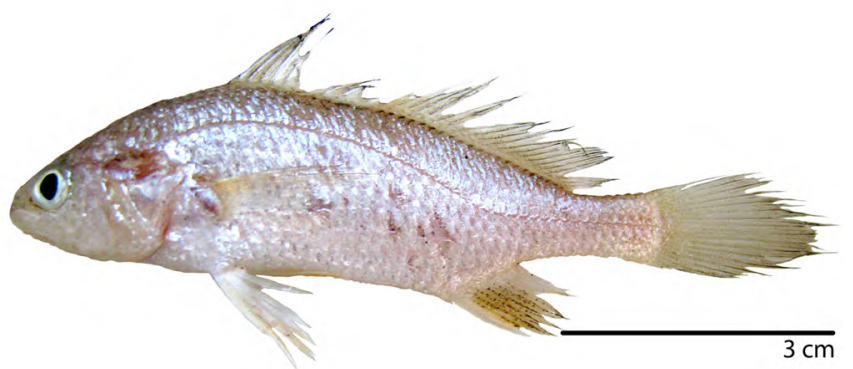

Figure 12. Stellifer brasiliensis (photo J. Garcia Jr). 
record is the northernmost occurrence and extends its geographical distribution.

Stellifer microps (Steindachner, 1864)

Cangoá

Coast: east

Stellifer naso (Jordan, 1889)

Cangoá

Coast: north and east

Stellifer rastrifer (Jordan, 1889)

Cangoá

Coast: north and east

Stellifer stellifer (Bloch, 1790)

Cangoá

Coast: north and east

Stellifer sp. (according to Menezes and Figueiredo, 1980) Cangoá

Coast: north and east

Umbrina coroides Cuvier, 1830

Coast: north

Remarks: reported by Dias (2006)

Family Mullidae

Mulloidichthys martinicus (Cuvier, 1829)

Saramunete listrado

Coast: north and east

Pseudupeneus maculatus (Bloch, 1793)

Saramunete

Coast: north and east

Family Pempheridae

Pempheris schomburgki Müller \& Troschel, 1848

Sardinha ouro

Coast: north and east

Family Chaetodontidae

Chaetodon ocellatus Bloch, 1787

Borboleta

Coast: north and east

Chaetodon striatus Linnaeus, 1758

Borboleta

Coast: north and east

Family Kyphosidae

Kyphosus sectatrix (Linnaeus, 1758)

Salema açú

Coast: north and east

Kyphosus vaigiensis (Quoy \& Gaimard, 1825)

Salema açú

Coast: north and east
Family Pomacanthidae

Centropyge aurantonotus Burgess, 1974

Coast: north and east

Holacanthus ciliaris (Linnaeus, 1758)

Parú verde

Coast: north and east

Holacanthus tricolor (Bloch, 1795)

Parú soldado

Coast: north and east

Pomacanthus arcuatus (Linnaeus, 1758)

Parú cagão

Coast: north and east

Pomacanthus paru (Bloch, 1787)

Parú frade

Coast: north and east

Family Cirrhitidae

Amblycirrhitus pinos (Mowbray, 1927)

Sarampinho

Coast: north and east

Family Pomacentridae

Abudefduf saxatilis (Linnaeus, 1758)

Sargentinho

Coast: north and east

Chromis flavicauda (Günther, 1880)

Coast: east

Remarks: reported by Floeter et al. (2003)

Chromis jubauna Moura, 1995

Tesourinha

Coast: north and east

Chromis multilineata (Guichenot, 1853)

Tesourinha

Coast: north and east

Chromis scotti Emery, 1968

Tesourinha

Coast: north and east

Microspathodon chrysurus (Cuvier, 1830) ${ }^{+}$

Donzela azul

Coast: north and east

Stegastes fuscus (Cuvier, 1830) *

Donzela marrom

Coast: north and east

Stegastes pictus (Castelnau, 1855)

Donzela bicolor

Coast: north and east

Stegastes uenfi Noveli, Nunan \& Lima, 2000 * Donzela marrom

Coast: north and east 
Stegastes variabilis (Castelnau, 1855) *

Donzela amarela

Coast: north and east

Family Labridae

Bodianus pulchellus (Poey, 1860)

Budião banana

Coast: north and east

Bodianus rufus (Linnaeus, 1758)

Budião banana

Coast: north and east

Clepticus brasiliensis Heiser, Moura \& Robertson, 2000 *

Budião vermelho

Coast: north and east

Doratonotus megalepis Günther, 1862

Coast: north and east

Halichoeres bivittatus (Bloch, 1791)

Budião bispo

Coast: north and east

Halichoeres brasiliensis (Bloch, 1791) *

Budião bispo

Coast: north and east

Halichoeres dimidiatus (Agassiz in Spix \& Agassiz, 1831)

Budião bispo

Coast: north and east

Halichoeres penrosei Starks, 1913 *

Budião bispo

Coast: north and east

Halichoeres poeyi (Steindachner, 1867)

Budião bispo

Coast: north and east

Halichoeres radiatus (Linnaeus, 1758)

Budião bispo

Coast: north

Remarks: on 17 May 2005, a specimen (LABIPE 25) was collected in João da Cunha reefs, northern coast, on reef substrate in about $30 \mathrm{~m}$ depth with fish trap. The specimen measured $23 \mathrm{~cm}$ total length and $62 \mathrm{~g}$ total weight (Figure 13). In the western Atlantic Ocean, the species is described to occur in Florida, Carolinas, Bermudas and Caribbean Sea and in Brazil on oceanic islands of Fernando de Noronha, Atol das Rocas and São Pedro e São Paulo (Menezes et al. 2003). Additionally, Rocha et al. (2005) reported the collect of two individuals of this species on the northeastern coast of Brazil, but without specifying the occurrence site or fish data. Thus, present record confirms the occurrence of this species on the Brazilian coast.

\section{Lachnolaimus maximus (Walbaum, 1792)}

Coast: east

Remarks: on 28 December 2010, a spear gun sport fishermen collected a specimen in front of Muriú beach, eastern coast, on rocky substrate in about $30 \mathrm{~m}$ depth. The specimen measured $56 \mathrm{~cm}$ total length and $5600 \mathrm{~g}$ total weight (Figure 14) and unfortunately, it was not possible to preserve it. Luiz et al. (2013) reported the presence of this species on the northeastern coast of Brazil, but without specifying the occurrence site or fish data. Thus, present record confirms the occurrence of this species on the Brazilian coast.

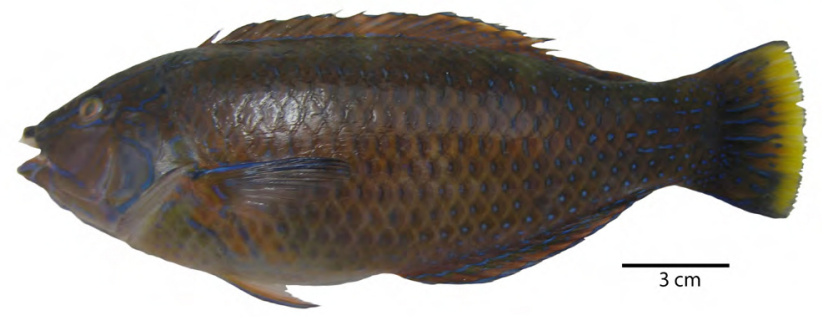

Figure 13. Halichoeres radiatus (photo J. Garcia Jr).

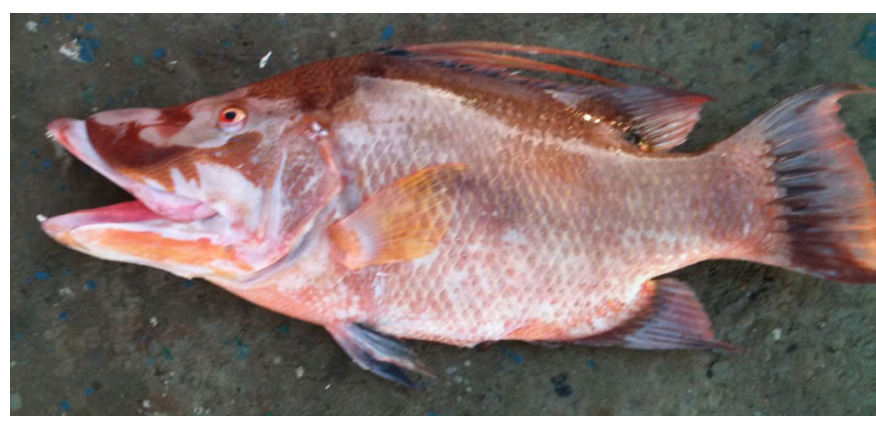

Figure 14. Lachnolaimus maximus (photo R. Barradas).

Thalassoma noronhanum (Boulenger, 1890) *

Peixe limpador

Coast: north and east

Xyrichtys incandescens Edwards \& Lubbock, 1981 *

Coast: north

Remarks: reported by Moura (2003)

Xyrichtys martinicensis Valenciennes in Cuvier \&

Valenciennes, 1840

Coast: east

Remarks: reported by Feitoza et al. (2005)

Xyrichtys novacula (Linnaeus, 1758)

Budião de areia

Coast: north and east

Xyrichtys splendens Castelnau, 1855

Budião de areia

Coast: north and east

Family Scaridae

Cryptotomus roseus Cope, 1871

Budião de alga

Coast: north and east 
Nicholsina usta Valenciennes, 1840

Budião verde

Coast: north

Scarus cf. guacamaia Cuvier, 1829

Coast: east

Remarks: reported by Floeter et al. (2003)

Scarus trispinosus (Valenciennes, 1840) *+

Budião azul

Coast: north and east

Scarus zelindae Moura, Figueiredo \& Sazima, 2001*+ Budião papagaio

Coast: north and east

Sparisoma amplum (Ranzani, 1842)

Budião jandaia

Coast: north and east

Sparisoma axillare (Steindachner, 1878) +

Budião batata

Coast: north and east

Sparisoma frondosum (Agassiz, 1831) ${ }^{+}$

Budião batata

Coast: north and east

Sparisoma radians (Valenciennes, 1840)

Budião de alga

Coast: north and east

Family Uranoscopidae

Astroscopus ygraecum (Steindachner, 1876)

Anequim

Coast: north

Family Tripterygiidae

Enneanectes altivelis Rosenblatt, 1960

Coast: north and east

Remarks: reported by Moura (2003) in northern coast and Feitoza (2001) in eastern coast

Family Dactyloscopidae

Dactyloscopus crossotus Starks, 1913

Coast: east

Remarks: reported by Feitoza (2001)

Dactyloscopus tridigitatus Gill, 1859

Coast: north and east

Platygillellus brasiliensis Feitoza, 2002 *

Coast: north and east

Family Blenniidae

Entomacrodus vomerinus (Valenciennes, 1836) *

Coast: north and east

Hypleurochilus pseudoaequipinnis Bath, 1994

Coast: north and east
Remarks: reported by Moura (2003) in northern coast and Feitoza (2001) in eastern coast

Omobranchus punctatus (Valenciennes, in Cuvier \& Valenciennes, 1836)

Coast: north and east

Remarks: exotic species recorded around shrimp farms; found in others areas of Brazilian coast (Soares et al. 2011)

Ophioblennius trinitatis Miranda Ribeiro, 1919*

Macaco

Coast: north and east

Scartella cristata (Linnaeus, 1758)

Maria da toca

Coast: north and east

Family Labrisomidae

Labrisomus cricota Sazima, Gasparini \& Moura, 2002 * Moré quatro olho

Coast: north and east

Labrisomus nuchipinnis (Quoy \& Gaimard, 1824)

Moré quatro olho

Coast: north and east

Malacoctenus delalandii (Valenciennes, 1836)

Macaquinho

Coast: north and east

Malacoctenus triangulatus Springer, 1959

Macaquinho

Coast: north and east

Paraclinus rubicundus Guimarães \& Bacellar, 2002 * Coast: east

Starksia brasiliensis (Gilbert, 1900) *

Coast: north and east

Starksia sp. (cited as Starksia sp. 2 in Moura, 2003)

Coast: north

Remarks: reported by Moura (2003)

Family Chaenopsidae

Emblemariopsis signifera (Ginsburg, 1942)

Coast: north

Remarks: reported by Moura (2003)

Family Gobiesocidae

Gobiesox barbatulus Starks, 1913

Pregador

Coast: east

Family Callionymidae

Paradiplogramus bairdi (Jordan, 1888)

Dragãozinho

Coast: north 
Family Eleotridae

Dormitator maculatus (Bloch, 1792)

Moré

Coast: north and east

Eleotris pisonis ( $\mathrm{Gmelin}, 1789$ )

Coast: north and east

Erotelis smaragdus (Valenciennes, 1837)

Coast: north and east

Guavina guavina (Valenciennes, 1837)

Moré

Coast: north and east

Family Gobiidae

Awaous tajasica (Lichtenstein, 1822)

Moré de rio

Coast: north and east

Bathygobius mystacium Ginsburg, 1947

Chupa areia

Coast: north and east

Bathygobius soporator (Valenciennes, 1837)

Chupa areia

Coast: north and east

Coryphopterus dicrus Böhlke \& Robins, 1960 Coast: north

Remarks: reported by Moura (2003)

Coryphopterus eidolon Böhlke \& Robins, 1960 Coast: east

Remarks: reported by Feitoza et al. (2005)

Coryphopterus glaucofraenum Gill, 1863

Moré de vidro

Coast: north and east

Coryphopterus thrix Böhlke \& Robins, 1960

Moré de vidro

Coast: north and east

Ctenogobius boleosoma (Jordan \& Gilbert, 1882)

Moré de vidro

Coast: north and east

Ctenogobius saepepallens (Gilbert \& Randall, 1968)

Moré de vidro

Coast: north and east

Ctenogobius shufeldti (Jordan \& Eigenmann, 1887)

Moré de vidro

Coast: north and east

Ctenogobius smaragdus (Valenciennes, 1837)

Moré de vidro

Coast: east
Elacatinus figaro Sazima, Moura \& Rosa, $1997^{*+}$

Neon

Coast: north and east

Evorthodus lyricus (Girard, 1858)

Coast: east

Gnatholepis cauerensis (Bleeker, 1853)

Coast: north and east

Gobionellus oceanicus (Pallas, 1770)

Corongo

Coast: north and east

Gobionellus stomatus Starks, 1913 *

Coast: east

Lythrypnus brasiliensis Greenfield, $1988^{*}$

Coast: north and east

Remarks: reported by Moura (2003) in northern coast and Feitoza (2001) in eastern coast

Microgobius meeki Evermann \& Marsh, 1899

Moré bocão

Coast: north and east

Priolepis dawsoni Greenfield, 1989

Coast: north and east

Psilotris celsa Böhlke, 1963

Coast: north

Remarks: reported by Moura (2003)

Risor ruber (Rosén, 1911)

Coast: north and east

Family Ptereleotridae

Ptereleotris randalli Gasparini, Rocha \& Floeter, 2001 Coast: north and east

Family Ephippidae

Chaetodipterus faber (Broussonet, 1782)

Enxada

Coast: north and east

Family Acanthuridae

Acanthurus bahianus Castelnau, 1855

Caraúna

Coast: north and east

Acanthurus chirurgus (Bloch, 1787)

Caraúna preta

Coast: north and east

Acanthurus coeruleus Bloch \& Schneider, 1801

Caraúna azul

Coast: north and east 
Family Sphyraenidae

Sphyraena barracuda (Walbaum, 1792)

Bicuda

Coast: north and east

Sphyraena guachancho Cuvier, 1829

Bicuda guaraná

Coast: north and east

Sphyraena picudilla Poey, 1860

Bicudinha

Coast: north and east

Family Trichiuridae

Trichiurus lepturus Linnaeus, 1758

Peixe espada

Coast: north and east

Family Scombridae

Acanthocybium solandri (Cuvier, 1832)

Cavala preta

Coast: north and east

Auxis thazard (Lacepède, 180o)

Bonito

Coast: north and east

Euthynnus alleteratus (Rafinesque, 1810)

Bonito pintado

Coast: north and east

Katsuwonus pelamis (Linnaeus, 1758)

Bonito listrado

Coast: north and east

Scomberomorus brasiliensis Collete, Russo \& Zavala-

Camin, 1978

Serra

Coast: north and east

Scomberomorus cavalla (Cuvier, 1829)

Cavala branca

Coast: north and east

Scomberomorus regalis (Bloch, 1793)

Serra pininxa

Coast: north and east

Thunnus atlanticus (Lesson, 1831)

Albacorinha

Coast: east

Family Stromateidae

Peprilus paru Linnaeus, 1758

Parú roliço

Coast: north and east
Order Pleuronectiformes

Family Paralichthydae

Citharichthys cornutus (Günther, 1880)

Solha

Coast: north and east

Citharichthys macrops Dresel, 1885

Solha

Coast: north and east

Citharichthys spilopterus Günther, 1862

Solha dente de velho

Coast: north

Cyclopsetta fimbriata (Goode \& Bean, 1885)

Linguado

Coast: north and east

Etropus crossotus Jordan \& Evermann, 1882 Solha

Coast: north and east

Paralichthys brasiliensis (Ranzani, 1842)

Linguado

Coast: north and east

Paralichthys isosceles Jordan, 1891

Coast: north

Remarks: reported by Dias (2006)

Syacium micrurum Ranzani, 1842

Linguado

Coast: north and east

Syacium papillosum (Linnaeus, 1758)

Linguado

Coast: north and east

Family Bothidae

Bothus lunatus (Linnaeus, 1758)

Solha

Coast: north and east

Bothus ocellatus (Agassiz, 1831)

Solha

Coast: north and east

Bothus robinsi Topp \& Hoff, 1972

Solha

Coast: north and east

Family Achiridae

Achirus achirus (Linnaeus, 1758)

Coast: north

Remarks: reported by Dias (2006)

Achirus lineatus (Linnaeus, 1758)

Solha

Coast: north and east 
Gymnachirus nudus Kaup, 1858

Solha

Coast: north

Trinectes microphthalmus (Chabanaud, 1928)

Solha

Coast: north and east

Trinectes paulistanus (Miranda Ribeiro, 1915)

Solha

Coast: north and east

Family Cynoglossidae

Symphurus diomedianus (Goode \& Bean, 1885)

Solha

Coast: north and east

Symphurus plagusia (Bloch \& Schneider, 1801)

Solha

Coast: north and east

Symphurus tessellatus (Quoy \& Gaimard, 1824)

Solha

Coast: north

Order Tetraodontiformes

Family Balistidae

Balistes capriscus Gmelin, 1789

Peixe porco

Coast: north and east

Balistes vetula Linnaeus, 1758

Cangulo verdadeiro

Coast: north and east

Canthidermis sufflamen (Mitchill, 1815)

Cangulo fernando

Coast: north and east

Melichthys niger (Bloch, 1786)

Pufa

Coast: north and east

Xanthichthys ringens (Linnaeus, 1758)

Cangulo guiné

Coast: east

Family Monacanthidae

Aluterus heudelotti Hollard, 1855

Cangulo

Coast: north and east

Aluterus monoceros (Linnaeus, 1758)

Cangulo patriota

Coast: north and east

Aluterus schoepfii (Walbaum, 1792)

Cangulo

Coast: north and east
Aluterus scriptus (Osbeck, 1765)

Cangulo

Coast: north and east

Cantherhines macrocerus (Hollard, 1855)

Cangulo

Coast: north and east

Cantherhines pullus (Ranzani, 1842)

Cangulo velho

Coast: north and east

Monacanthus ciliatus (Mitchill, 1818)

Porquinho

Coast: north and east

Stephanolepis hispidus (Linnaeus, 1766)

Porquinho

Coast: north and east

Stephanolepis setifer (Bennett, 1831)

Porquinho

Coast: north

Family Ostraciidae

Acanthostracion polygonius Poey, 1876 Cofre

Coast: north and east

Acanthostracion quadricornis (Linnaeus, 1758) Cofre

Coast: north and east

Lactophrys bicaudalis (Linnaeus, 1758)

Cofre

Coast: north

Lactophrys trigonus (Linnaeus, 1758)

Cofre

Coast: north and east

Family Tetraodontidae

Canthigaster figueiredoi Moura \& Castro, 2002

Baiacú mirim

Coast: north and east

Canthigaster jamestyleri Moura \& Castro, 2002

Baiacú mirim

Coast: north

Remarks: on 12 August 2005, a specimen (LABIPE 26) was collected in the Urca do Minhoto, northern coast, on reef substrate in about $20 \mathrm{~m}$ depth with plastic bag while SCUBA diving. The specimen measured $6 \mathrm{~cm}$ total length and $10 \mathrm{~g}$ total weight (Figure 15). Canthigaster jamestyleri differs from all Atlantic congeners (more similar to $C$. figueiredoi) by the presence of a small irregular dark spot on the dorsal fin base and the absence of dark dorsal and ventral margins on the caudal fin (Moura and Castro 2002). In the western Atlantic Ocean the species is described to occur in the southern USA and Gulf of 


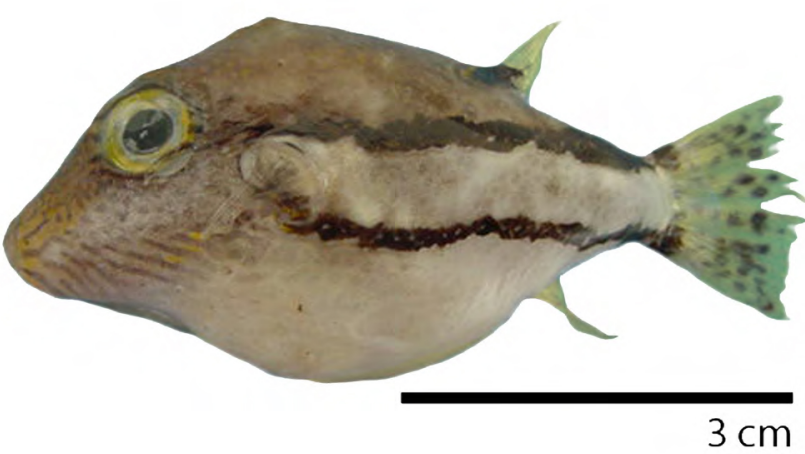

Figure 15. Canthigaster jamestyleri (photo J. Garcia Jr).

Mexico (Moura and Castro 2002). Thus, present record is the first occurrence of this species on the Brazilian coast.

Colomesus psittacus (Bloch \& Schneider, 1801)

Baiacú camisa de meia

Coast: north and east

Lagocephalus laevigatus (Linnaeus, 1766)

Baiacú guarajuba

Coast: north and east

Sphoeroides dorsalis Longley, 1934

Baiacú mirim

Coast: north

Sphoeroides greeleyi Gilbert, 1900

Baiacú mirim

Coast: north and east

Sphoeroides pachygaster (Müller \& Troschel, 1848)

Baiacú mirim

Coast: north and east

Sphoeroides spengleri (Bloch, 1785)

Baiacú pinima

Coast: north and east

Sphoeroides testudineus (Linnaeus, 1758)

Baiacú pintado

Coast: north and east

Sphoeroides tyleri Shipp, 1974

Baiacú pintado

Coast: north and east

Family Diodontidae

Chilomycterus antennatus (Cuvier, 1816)

Baiacú de espinho

Coast: north

Chilomycterus spinosus (Linnaeus, 1758)

Baiacú de espinho

Coast: north and east
Cyclichthys antillarum Jordan \& Rutter, 1897

Baiacú de espinho

Coast: north and east

Diodon holocanthus Linnaeus, 1758

Baiacú de espinho

Coast: north and east

Diodon hystrix Linnaeus, 1758

Baiacú de espinho

Coast: north and east

Family Molidae

Mola mola (Linnaeus, 1758)

Peixe lua

Coast: north and east

Ranzania laevis (Pennant, 1776)

Coast: east

\section{DISCUSSION}

At present, 459 species of coastal fishes are known from the Rio Grande do Norte state (RN). Soares (1988) recorded the occurrence of Lycengraulis barbouri (a synonym of L. batesii), Trachinotus glaucus (a synonym of T. ovatus) and Ogcocephalus radiatus in RN coast. By analyzing specimens identified as belonging to these species at MMOL, it was verified that in fact, they are L. grossidens, T. goodei and O. vespertilio, respectively. According to the latest compilation, 1,297 species of marine fishes were found on the Brazilian coast (Menezes et al. 2003), of which about 35\% is recorded in the coast of RN. Most species presented here (358) was recorded on both coasts; however, 52 species were exclusively recorded on the northern coast and 42 species exclusively on the eastern coast. These exclusive records may be the result of differences in habitat characteristics between these coasts. As example, estuarine species like Anchoa januaria, A. tricolor, Lycengraulis batesii, Achirus achirus and Gymnachirus nudus were recorded only in northern coast, where are the larger estuarine habitats of RN. Otherwise, oceanic species like Polymixia lowei, Thunnus atlanticus, Sphoeroides pachygaster and Ranzania laevis were recorded only in the eastern coast, where the continental shelf is narrower. With regard to the number of species, the results demonstrate that the coastline of $\mathrm{RN}$ is richer than it was suspected, and that this can be considered reasonably known to date. However, surveys on deeper habitats as well as the use of higher sampling effort may result in additional records. The composition of fish fauna of RN coast is recognized for having high similarity to the fish fauna of the neighbor states of Paraíba and Pernambuco (Floeter et al. 2001; Moura 2003; Feitoza et al. 2005; Freitas and Lotufo 2014). However, this similarity was always tested using the fish fauna of a few localities of RN rather than all species occurring along the coast. Previously zoogeographical 
hypothesis based only on small-scale local lists or on few families should be tested using a comprehensive regional checklist, as presented herein. Of the 459 species recorded in RN, 27 are Brazilian endemic fishes and 37 species have recently been included in the National List of Endangered Fauna, under some degree of threat (MMA, 2014). Of these 37 species, 27 are captured by commercial fishing in RN, and now legally prohibited from being caught and marketed. The large number of new records for the RN coast (83) reflects the existence of few local inventories and shows how the lack of studies influences the state of knowledge in a specific area. Ultimately, this can affect the quality and effectiveness of management strategies applied to the fish stocks. As an example, between 2000 and 2005, fishery monitoring sponsored by the government on the RN coast registered a capture of approximately 2,385 tons in the category named "serra", represented by Scomberomorus brasiliensis (MMA 2006). However, our records show that $S$. regalis, a morphologically similar species, is also captured simultaneously in the same habitats as $S$. brasiliensis, and is included in the same category. The same occurs with species of Centropomus spp., Coryphaena spp., Epinephelus spp., Mugil spp., Sparisoma spp., family Ariidae and order Pleuronectiformes. Therefore, only one stock is being evaluated when in fact there are two or more. Only with a better understanding of the local fish fauna and a monitoring designed by species, it will be possible properly to monitor the level of exploitation of local fish stocks. In this sense, this checklist provides a great increment in the knowledge of the coastal fishes of RN and represents the first steps for improve the fishery management of this area.

\section{ACKNOWLEDGEMENTS}

This work represents part of the M.Sc. research of J. Garcia Jr. who thanks Coordenação de Aperfeiçoamento de Pessoal de Nível Superior (CAPES) for financial support. We are grateful to Waldecir S. Costa (in memorian) and Wellington S. Xavier for helping with specimens collections. We thank Ronaldo Barradas for providing his collect data of Lachnolaimus maximus. Cláudio L.S. Sampaio and Bertran M. Feitoza greatly helped with the identification of some specimens.

\section{LITERATURE CITED}

Amaro, V.E. and A.T.S. Ferreira. 2012. Imagens do AQUA-MODIS aplicadas à estimativa dos valores de clorofila-a e da temperatura da superfície do mar na zona offshore da Bacia Potiguar no Rio Grande do Norte. Revista de Geologia 25(HIDROSEMA-UFRN): 128-142. http://www.revistadegeologia.ufc.br/documents/revista/ 2012/oge_2012.pdf

Camargo, M. and V. Isaac. 2001. Os peixes estuarinos da região norte do Brasil: Lista de espécies e considerações sobre a sua distribuição geográfica. Boletim do Museu Paraense Emílio Goeldi, Série Zoológica 17(2): 133-157. http://repositorio.museu-goeldi.
br/jspui/bitstream/123456789/723/1/B\%2oMPEG\%2OZoo\%20 17(2)\%202001\%20CAMARGO.PDF

Carvalho-Filho, A. 1999. Peixes: Costa Brasileira. Editora Melro. 320 pp. Dias, T.L.P. 2006. Os peixes, a pesca e os pescadores da Reserva de Desenvolvimento Sustentável Ponta do Tubarão (MacauGuamaré/RN), Brasil [Ph.D. thesis]. Paraíba: Universidade Federal da Paraíba. 162 pp.

Eschmeyer, W.N. (ed). 2015. Catalog of fishes: genera, species, references. Accessed at http://research.calacademy.org/ research/ichthyology/catalog/fishcatmain.asp, 30 April 2015.

Feitosa, C.V., D.A.S. Pimenta and M.E. Araújo. 2002. Ictiofauna recifal dos Parrachos de Maracajaú (RN) na área dos flutuantes: Inventário e estrutura da comunidade. Arquivos de Ciências do Mar 35: 39-50. http://labomar.ufc.br/images/stories/arquivos/ ArqCienMar/V35_2002/acm_2002_35_06.pdf

Feitoza, B.M. 2001. Composição e Estrutura da comunidade de peixes recifais da Risca do Zumbi, Rio Grande do Norte [M.Sc. dissertation]. Paraíba: Universidade Federal da Paraíba. 157 pp.

Feitoza, B.M., R.S. Rosa and L.A. Rocha. 2005. Ecology and zoogeography of deep-reef fishes in northeastern Brazil. Bulletin of Marine Science 76(3): 725-742. http://www.ingentaconnect. com/content/umrsmas/bullmar/2005/00000076/00000003/ artooo10

Floeter, S.R.; R.Z.P. Guimarães, L.A. Rocha, C.E.L. Ferreira, C.A. Rangel and J.L. Gasparini. 2001. Geographic variation in reef-fish assemblages along the Brazilian coast. Global Ecology and Biogeography 10(4): 423-431. doi: 10.1046/j.1466822X.2001.00245.X

Floeter, S.R., J.L. Gasparini, L.A. Rocha, C.E.L. Ferreira, C.A. Rangel and B.M. Feitoza. 2003. Brazilian reef fish fauna: checklist and remarks. Accessed at http://www.brazilianreeffish.cjb.net, 14 June 2014.

Freitas, J.E.P. and T.M.C. Lotufo. 2014. Reef fish assemblage and zoogeographic affinities of a scarcely known region of the western equatorial Atlantic. Journal of the Marine Biological Association of the United Kingdom 1-11. doi: 10.1017/So025315414001404

Garcia Jr, J, L.F. Mendes, C.L.S. Sampaio and J.E. Lins Oliveira. 2010. Biodiversidade marinha da Bacia Potiguar: Ictiofauna. Museu Nacional. 195 pp.

Gasparini, J.L. and S.R. Floeter. 2001. The shore fishes of Trindade Island, western South Atlantic. Journal of Natural History 35(11): 1639-1656. doi: 10.1080/002229301317092379

Lumpkin, R. and S.L. Garzoli. 2005. Near-surface circulation in the Tropical Atlantic Ocean. Deep-Sea Research I 52: 495-518. doi: 10.1016/j.dsr.2004.09.001

Luiz, O.J., S.R. Floeter, L.A. Rocha and C.E.L. Ferreira. 2013. Perspectives for the lionfish invasion in the South Atlantic: Are Brazilian reefs protected by the currents? Marine Ecology Progress Series 485: 1-7. doi: 10.3354/meps10383

Marceniuk, A.P. 2005. Redescrição de Genidens barbus (Lacépède, 1803) e Genidens machadoi (Miranda-Ribeiro, 1918), bagres marinhos (Siluriformes, Ariidae) do Atlântico Sul Ocidental. Papéis avulsos de Zoologia 45(11): 111-125. doi: 10.1590/Soo3110492005001100001

Marceniuk, A.P. and N.A. Menezes. 2007. Systematics of the family Ariidae (Ostariophysi, Siluriformes), with a redefinition of the genera. Zootaxa 1416: 1-126. http://www.mapress.com/ zootaxa/2007f/zto1416p126.pdf

Martins-Juras, I.A.G., A.A. Juras and N.A. Menezes. 1987. Relação preliminar dos peixes da Ilha de São Luís, Maranhão, Brasil. Revista Brasileira de Zoologia 4(2): 105-113. doi: 10.159o/So10181751987000200003

Mattox, G.M.T., G.F. Gondolo and P.T.M. Cunningham. 2008. Atherinella blackburni (Schultz, 1949) at Itamambuca Beach, Ubatuba, SP: ecological characterization and distribution on the Brazilian coast (Teleostei: Atheriniformes: Atherinopsidae). 
Brazilian Journal of Biology 68(2): 307-313. http://www. producao.usp.br/handle/BDPI/12377

Menezes, N.A. and J.L. Figueiredo. 1980. Manual de peixes marinhos do sudeste do Brasil. IV. Teleostei (3). Museu de Zoologia da Universidade de São Paulo. 96 pp.

Menezes, N.A., P.A. Buckup, J.L. Figueiredo and R.L. Moura. 2003. Catálogo das espécies de peixes marinhos do Brasil. Museu de Zoologia da Universidade de São Paulo. 159 pp.

Menni, R.C., F.V. Hazin and R.P. Lessa. 1995. Occurrence of the ragged-tooth shark, Odontaspis ferox, in the western equatorial Atlantic. Chondros 5(4):3.

MMA. 2006. Relatório final do projeto de monitoramento da atividade pesqueira do litoral do Brasil-Projeto Estatpesca. Ministério do Meio Ambiente/Instituto Brasileiro do Meio Ambiente e dos Recursos Naturais Renováveis. Brasília. 328 pp.

MMA. 2014. Lista Nacional Oficial de Espécies da Fauna Ameaçadas de Extinção - Peixes e Invertebrados Aquáticos. Ministério do Meio Ambiente. Brasília. 5pp.

Montag, L.F.A., A.A. Albuquerque, T.M.S. Freitas and R.B. Barthem. 2009. Ictiofauna de campos alagados da Ilha do Marajó, Estado do Pará, Brasil. Biota Neotropical 9(3): 241-253. doi: 10.1590/ S1676-06032009000300024

Moura, R.L. 2003. Riqueza de espécies, diversidade e organização de assembléias de peixes em ambientes recifais: um estudo ao longo do gradiente latitudinal da costa brasileira [Ph.D. thesis]. São Paulo: Universidade de São Paulo. 620 pp.

Moura, R.L. and R.M.C. Castro. 2002. Revision of atlantic sharpnose pufferfishes (Tetraodontiformes: Tetraodontidae: Canthigaster), with description of three new species. Proceedings of the Biological Society of Washington 115: 32-50. http://biostor.org/ reference/80937

Nelson, J.S. 2006. Fishes of the world. Hoboken: John Wiley \& Sons. $601 \mathrm{pp}$.

Nimer, E. 1989. Climatologia do Brasil. Instituto Brasileiro de Geografia e Estatística. 422 pp.

Oliveira, V.S. and J.M. Barbosa. 2010. Ocorrência do "Spanish Flag" Gonioplectrus hispanus (Cuvier, 1828) na costa de Pernambuco, Brasil. Revista Brasileira de Engenharia de Pesca 5(1): 93-97.
http://ppg.revistas.uema.br/index.php/REPESCA/article/ viewFile/276/278

Ramos, R.T.C. 1994. Análise da composição e distribuição da fauna de peixes demersais da plataforma continental da Paraíba e estados vizinhos. Revista Nordestina de Biologia 9(1): 1-30. http:// periodicos.ufpb.br/ojs/index.php/revnebio/article/view/16704

Rocha, L.A., D.R. Robertson, J. Roman and B.W. Bowen. 2005. Ecological speciation in tropical reef fishes. Proceedings of the Royal Society B 272: 573-579. doi: 10.1098/2004.3005

Soares, B.E., R.D.O. Raiol and L.F.A. Montag. 2011. Occurrence of the non-native blenny Omobranchus punctatus (Valenciennes, 1836) (Perciformes: Blenniidae) in the Amazon coastal zone, Brazil. Aquatic Invasions 6 (Supplement 1): S39-S437. doi: 10.3391/ ai.2011.6.S1.009

Soares, L.H. 1988. Catálogo dos peixes do litoral do Estado do Rio Grande do Norte, Brasil. Boletim do Departamento de Oceanografia e Limnologia da Universidade Federal do Rio Grande do Norte 7: 1-39.

Yokota, L. 2005. Caiçara do Norte: Um berçário de tubarões e raias? [M.Sc. dissertation]. Pernambuco: Universidade Federal de Pernambuco. $88 \mathrm{pp}$.

Vasconselos-Filho, A.L. and A.M.E. Oliveira. 1999. Composição e ecologia da ictiofauna do canal de Santa Cruz (Itamaracá - PE, Brasil). Trabalhos de Oceanografia da Universidade Federal de Pernambuco 27(1): 101-113. http://www.revista.ufpe.br/tropicaloceanography/ artigos_completos_resumos_t_d/27_1999_1_vasconcelos_filho.pdf

Vital, H., M.P. Gomes, W.F. Tabosa, E.P. Frazão, C.L.A. Santos and J.S. Plácido. 2010. Characterization of the Brazilian continental shelf adjacent to Rio Grande do Norte State, NE Brazil. Brazilian Journal of Oceanography 58(special issue): 43-54. doi: 10.159o/ S1679-87592010000500005

Authors' contribution statement: JGJr, MFN and JELO collected and identified specimens and wrote the text.

Received: August 2014

Accepted: April 2015

Academic editor: Osmar J. Luiz 